\title{
PERAN STRATEGIC ENTREPRENEURSHIP DALAM MEMBANGUN SUSTAINABLE COMPETITIVE ADVANTAGE
}

\author{
Agustinus Dedy Handrimurtjahjo \\ Management Department, School of Business Management, BINUS University \\ Jln. K.H. Syahdan No. 9, Palmerah, Jakarta Barat 11480 \\ ahandrimurtjahjo@binus.edu
}

\begin{abstract}
Strategic entrepreneurship has emerged as a new concept in examining convergence in entrepreneurship studies (opportunity-seeking behavior) and strategic management (advantage-seeking behavior). Studies in the area of strategic management have gradually exposed the relationship between strategic management and entrepreneurship: entrepreneurial strategy making; intrapreneurship; entrepreneurial strategic posture within organizations; entrepreneurial orientation; strategic management integration as a context for entrepreneurial actions; and entrepreneurship theory with strategic management and the resource-based view (RBV). A conceptual model of SE that has been developed by Ireland et al. suggested that a firm which linearly and sequentially: employs an entrepreneurial mindset to identify opportunities; manages resources strategically to tackle the opportunity; applies creativity and innovation; and generates a competitive advantage is strategic and entrepreneurship operation. Managers must maximize the pursuit of new business opportunities while simultaneously maximize the generation and application of temporary competitive advantages to sustainably create organizational value. This paper develops a conceptual framework that demonstrate the role of strategic entrepreneurship in building sustainable competitive advantage.
\end{abstract}

Keywords: strategic management, entrepreneurship, strategic entrepreneurship, competitive advantage

\begin{abstract}
ABSTRAK
Kewirausahaan strategis telah muncul sebagai konsep baru dalam menguji konvergensi dalam studi tentang kewirausahaan (perilaku mencari peluang) dan manajemen strategis (perilaku mencari keunggulan). Studi dalam bidang manajemen strategis secara bertahap telah memaparkan hubungan antara manajemen strategis dan kewirausahaan; pembuatan strategi kewirausahaan; intrapreneurship; postur strategis kewirausahaan dalam organisasi; orientasi kewirausahaan; perpaduan manajemen strategis sebagai konteks tindakan kewirausahaan; dan teori kewirausahaan dengan manajemen strategis dan pandangan berbasis sumber daya. Model konsep kewirausahaan strategis yang telah dikembangkan oleh Ireland dkk menyarankan bahwa perusahaan yang secara linier dan berurutan: menggunakan cara berpikir kewirausahaan untuk mengidentifikasi peluang; mengelola sumber daya secara strategis untuk menghadapi peluang; menerapkan kreativitas dan inovasi dan menghasilkan keunggulan bersaing merupakan tindakan secara strategis dan kewirausahaan. Manajer harus memaksimalkan dalam mengejar peluang bisnis baru sekaligus secara simultan memaksimalkan hasil dan aplikasi keunggulan bersaing untuk menciptakan nilai organisasi secara berkelanjutan. Paper ini mengembangkan kerangka konsep yang menunjukkan peran kewirausahaan strategis dalam membangun keunggulan bersaing yang berkelanjutan.
\end{abstract}

Kata kunci: manajemen strategis, kewirausahaan, kewirausahaan strategis, keunggulan bersaing 


\section{PENDAHULUAN}

Strategic Entrepreneurship (SE) merupakan perilaku yang simultan dalam mencari peluang (opportunity-seeking) dan sekaligus mencari keunggulan (advantage-seeking) kinerja perusahaan yang unggul (Ireland et al., 2003). Strategic Entrepreneurship telah menciptakan bidang riset baru, tetapi agar dapat memanfatkan peluang riset baru yang ditawarkan, pemahaman lebih mendalam tentang riset ini harus dikembangkan (Kraus et al, 2011). Pemahaman tentang Strategic Entrepreneurship pada tahap awal mempertanyakan apakah SE merupakan kerangka, model, teori, paradigma, konsep atau titik penghubung (point of interface) yang sederhana (Kraus et al, 2011; Schindehutte \& Morris, 2009). Mekipun model yang berkaitan dengan SE telah muncul (antara lain Ireland et al, 2003; Ireland \& Webb 2007; Kyrgidou \& Hughes, 2010; Shulman et al., 2011, Kraus et al., 2011), model baru perlu dikembangkan dan ruang lingkup yang diadopsi dalam model yang diusulkan perlu dianalis secara lebih rinci. Studi yang dilakukan oleh mereka mencoba untuk meningkatkan pemahaman tentang Strategic Entrepreneurship. Penekanan pada membangun model dengan melihat ruang lingkup integral dari konsep dan memperoleh pemahaman mendalam tentang ruang lingkup dan interaksinya. Pada model akhir, sejumlah ruang lingkup yang rasional telah dipilih: jumlah ruang lingkup harus cukup besar untuk menangkap esensi konsep, tetapi jumlah seharusnya tidak begitu besar sehingga membuat model terlalu rumit.

Studi tentang Strategic Entrepreneurship yang dilakukan oleh Hitt et al. (2001) menelusuri integrasi Strategic Entrepreneurship dalam beberapa ruang lingkup organisasi yang penting untuk memasukkan jaringan dan aliansi eksternal, sumber daya dan pembelajaran organisasional, inovasi dan internasionalisasi. Risetnya menguji baik secara tradisional (seperti teori kontingensi dan strategic fit) maupun teori baru (seperti cultural entrepreneurship dan business model drivers). Studinya juga memadukan, memperluas, dan menguji teori dan riset dari entreprenuership dan strategic management dalam cara-cara baru seperti creative destruction diskontinuities), resource based view, organizational learning, network theory, transaction cost dan institutional theory.

Ireland et al. (2003) menyatakan bahwa secara relatif perusahaan yang kecil dan entrepreneurial efektif dalam mengidentifikasi peluang namun kurang sukses dalam mengembangkan keunggulan kompetitif yang diperlukan untuk menilai secara tepat dalam menetapkan peluang tersebut. Sebaliknya, perusahaan yang besar dan mapan sering secara relatif lebih efektif dalam menetapkan keunggulan kompetitif namun kurang mampu dalam mengidentifikasi peluang baru. Ireland et al. (2003) berpendapat bahwa SE merupakan variabel yang unik dan berbeda, yang melaluinya perusahaan mampu menciptakan kemakmuran. Entrepreneurial mindset, entreprenurial culture dan entreprenurial leadership, sumber daya manajemen strategis dan penerapan kreativitas untuk mengembangkan inovasi merupakan dimensi penting dalam SE.

Sementara itu Kyrgidou dan Hughes (2010) melakukan studi tentang pemahaman SE dengan mengkaji konsep untuk memetakan komponen inti dan menggambarkan arah riset bagi bidang yang sedang muncul dan menggairahkan ini. Analisis ruang lingkup Strategic Entrepreneurship menyatakan delapan komponen inti diambil dari entrepreneuship dan strategic management yang menangkap kondisi yang diperlukan untuk aplikasinya (Kyrgidou \& Hughes, 2010). Sedangkan studi yang dilakukan oleh Shulman et al., (2011) bertujuan untuk menyajikan pengembangan model unit Strategic Entrepreneurship (SEU) sebagai alternatif cara bagi perusahaan besar untuk memanfaatkan semangat entrepreneurial dan penciptaan hak intelektual. Beberapa model organisasional yang bersaing dikritik oleh Shulman et al. (2011) berdasarkan faktor yang akan berdampak pada pertumbuhan dan kinerja tingkat pengembalian (return) dalam unit. Unit organisasional yang diuji oleh Shulman et al. (2011) meliputi corporate entrepreneurship, corporate spinout, corporate venturing, corporate venturing dengan partisipasi kapitalis venture, dan SEU. 
Studi yang dilakukan oleh Kraus et al. (2011), menggunakan pendekatan konfigurasi sebagai basis teori. Konfigurasi merupakan model konsep yang diekpresikan dengan sekumpulan variabel yang saling berhubungan. Variabel dapat diperkuat masing-masing atau menutupi dampak masingmasing dan berbagai subkelompok variabel dapat menggambarkan ruang lingkup yang berbeda. Pengembangan pendekatan konfigurasi mengacu pada metode riset dengan konfigurasi baru dibangun. Kekuatan dari pendekatan ini memungkinkan bangunan model konsep yang terperinci terdiri dari sejumlah besar variabel dengan hubungan yang rumit dan saling berkaitan. Dasar untuk pengembangan konfigurasi yang dilakukan dalam studi saat ini merupakan kajian menyeluruh dalam literatur akademik yang masih baru dan sedang tumbuh dalam bidang Strategic Entrepreneurship (Kraus et al. 2011).

Berdasarkan hasil studi yang dilakukan oleh Hitt et al. (2001), Ireland et al. (2003), Kyrgidou dan Hughes (2010), Shulman et al., (2011), Kraus et al., (2011), paper ini bertujuan untuk menemukan peran SE dalam membangun keunggulan kompetitif dan kinerja organisasional.

\section{Kerangka Teoretis}

Studi tentang Strategic Entrepreneurship melibatkan tindakan secara berbeda kombinasi entreprenurial (fokus pada peluang) dengan tindakan secara esensi karakteristik strategis (penciptaan keunggulan strategis) Kyrgidou dan Hughes (2010). Konsep ini mungkin dipandang sebagai perluasan tentang pembuatan strategi entreprenuerial, menjadi model strategi yang memadukan pembuatan strategi dengan kemampuan membuat keputusan yang cepat dalam lingkungan yang berubah (Bird, 1988). Secara khusus, Mintzberg dan Waters (1982) mencirikan pembuatan strategi entrepreneurial dengan tingkat kesengajaan dan visi yang jelas untuk berubah. Bird (1988) menguatkan konsep visi dalam Strategic Entrepreneurship, dengan mengidentifikasi fokus pada saat ini dengan visi perusahaan di masa depan. Eisendhardt dan Martin (2000) di sisi lain menguatkan fleksibilitas dalam pendapat mengelola kekacauan perubahan, mengusulkan enam proses mendasar dengan tujuan membuat entrepreneurship sebuah praktik strategis yang standar. Proses tersebut meliputi improvisasi, co-adaptation, patching, regeneration, experimentation, dan time pacing (Kyrgidou \& Hughes, 2010).

Kerangka enam proses Eisenhardt dan Martin (2000) serupa dengan enam ruang lingkup yang diidentifikasikan oleh Ireland et al (2001): innovations, network (access to resources), internationalization, organizational learning (transferring knowledge and developing resources), growth and top management teams and governance (effective selection and implementation strategies). Kemudian Hit et al. (2001) merevisi ruang lingkup dengan menambah penekanan pada resources, competencies dan capabilities untuk mengembangkan keunggulan kompetitif yang berkelanjutan (SCA) ketika melakukan perilaku entrepreneurial. Sehingga dengan menambahkan komponen resource management dan dynamic capability, model Strategic Entrepreneurship terdiri dari delapan komponen yaitu: opportunity identification, innovation, acceptance of risk, flexibility, vision, growth, resource management dan dynamic capability.

Studi yang dilakukan oleh Ireland et al. (2003) yang memfokuskan variabel SE pada bagaimana perilaku mencari peluang dan keunggulan sehingga dapat diintegrasikan untuk menciptakan keseimbangan antara kedua perilaku untuk mencapai sustainable competitive advantage dinilai oleh Kyrgidou dan Hughes (2010) telah gagal mempertimbangkan pertimbangan waktu dan ruang berkaitan dengan "balance". Oleh karena itu, Kyrgidou dan Hughes (2010) memperbaiki dan mengembangkan model praktis Strategic Entrepreneurship dengan mempertahankan tahap struktur utama Ireland et al. (2003) sebagai logika yang melahirkan kemiripan delapan komponen utama Strategic Entrepreneurship. Meskipun demikian, untuk mengatasi masalah linieritas, perusahaan terlihat harus melakukan lagi tahap identifikasi peluang, mengelola sumber daya secara strategis dengan bundling, rebundling, acquiring, dan divesting resources (Simons et al., 2007) dan eksploitasi penciptaan dan penyebaran inovasi (Kyrgidou \& Hughes, 2010). Model Strategic Entrepreneurship 
yang dirancang oleh Ireland et al. (2003) dan kemudian dikembangkan oleh Kyrgidou dan Hughes (2010) adalah sebagai berikut :

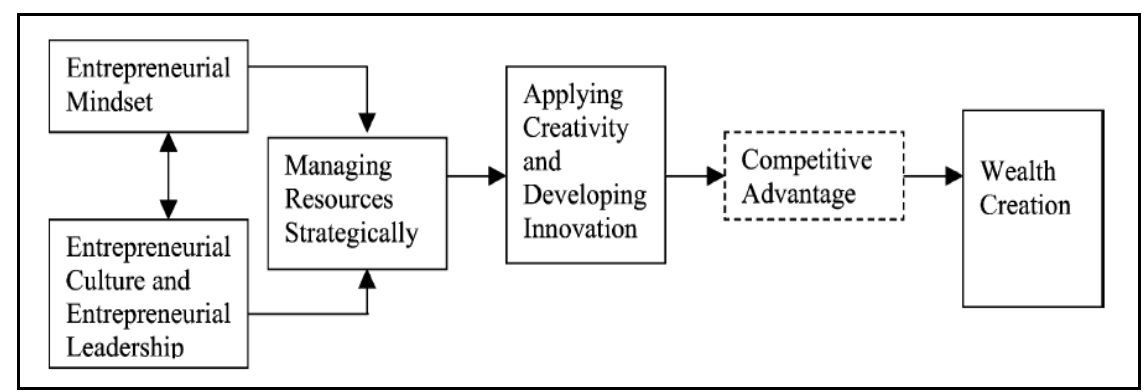

Gambar 1 Model Praktis Strategic Entrepreneurship (Ireland et al., 2003)

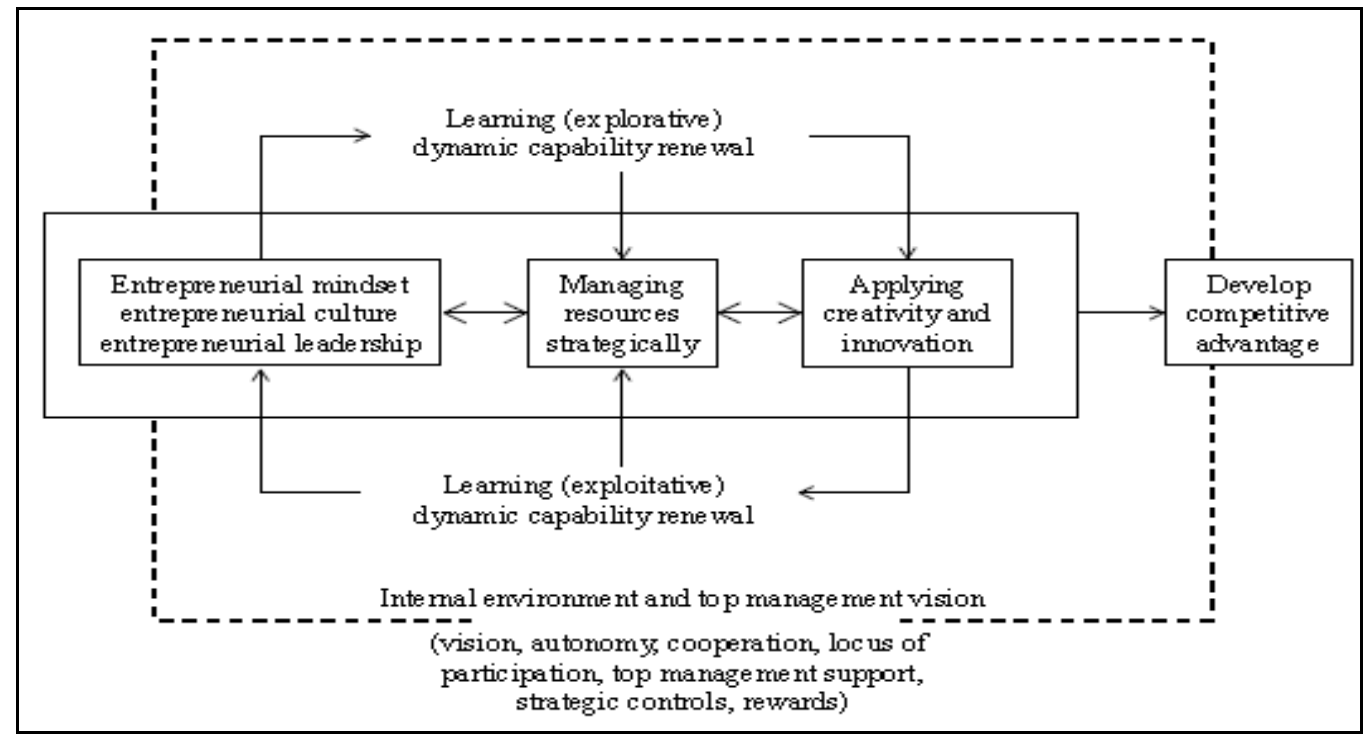

Gambar 2 Model Strategic Entrepreneurship (Kyrgidou dan Hughes, 2010)

Kraus et al., (2011) dalam studinya memilih pandangan teoretis yang berbeda untuk usaha yang sama, yaitu pendekatan konfigurasi. Mereka mendasarkan pada Miller (1987) yang pada awalnya mengusulkan penggunaan empat domain seperti leadership, structure, strategy, dan environment untuk mengidentifikasi konfigurasi optimal dalam riset strategi. Model Miller (1987) telah dibahas lebih lanjut oleh Dess et al. (1993), Mugler (2004), dan Harms et al. (2007, 2009), kemudian mengusulkan bahwa domain leadership seharusnya dipahami sebagai pendiri, karena pendiri merupakan kekuatan yang menggerakkan (driving force) pada berbagai perusahaan start-up. Meskipun demikian, dari waktu ke waktu, dalam perusahaan kecil menengah (SME) dan besar, pendiri mungkin tidak memainkan peran yang signifikan lagi. Oleh karena itu, Kraus et al., (2011) mengusulkan penggabungan dua domain tersebut menjadi entrepreneurial leadership, yang mengintegrasikan karakteristik entrepreneurial pendiri dengan karakteristik pemimpin saat ini. Dengan memodifikasi model Harms et al, (2007), Kraus et al., (2011) mengusulkan pemisahan domain struktur organisasi, sumber daya, dan kapabilitas. Dalam pandangan mereka, sumber daya adalah dasar bagi domain lain dalam konfigurasi dan kapabilitas adalah hasil interaksi sumberdaya. Kraus et al., (2011) kemudian mengusulkan enam domain (ruang lingkup) yang saling berhubungan 
untuk model konsep yang baru terdiri dari: resources, capabilities, strategy, entrepreneur, environment dan organizational structure. Model yang mengombinasikan model proses komprehensif Strategic Entrepreneurship Ireland et al. (2003), domain yang diusulkan oleh Miller (1970 dan diadopsi dari Harms et al., 2009) tersebut menunjukkan perbedaan dalam situasi perusahaan selama proses pertumbuhan. Model yang dikembangkan oleh Kraus et al., (2011) adalah sebagai berikut:

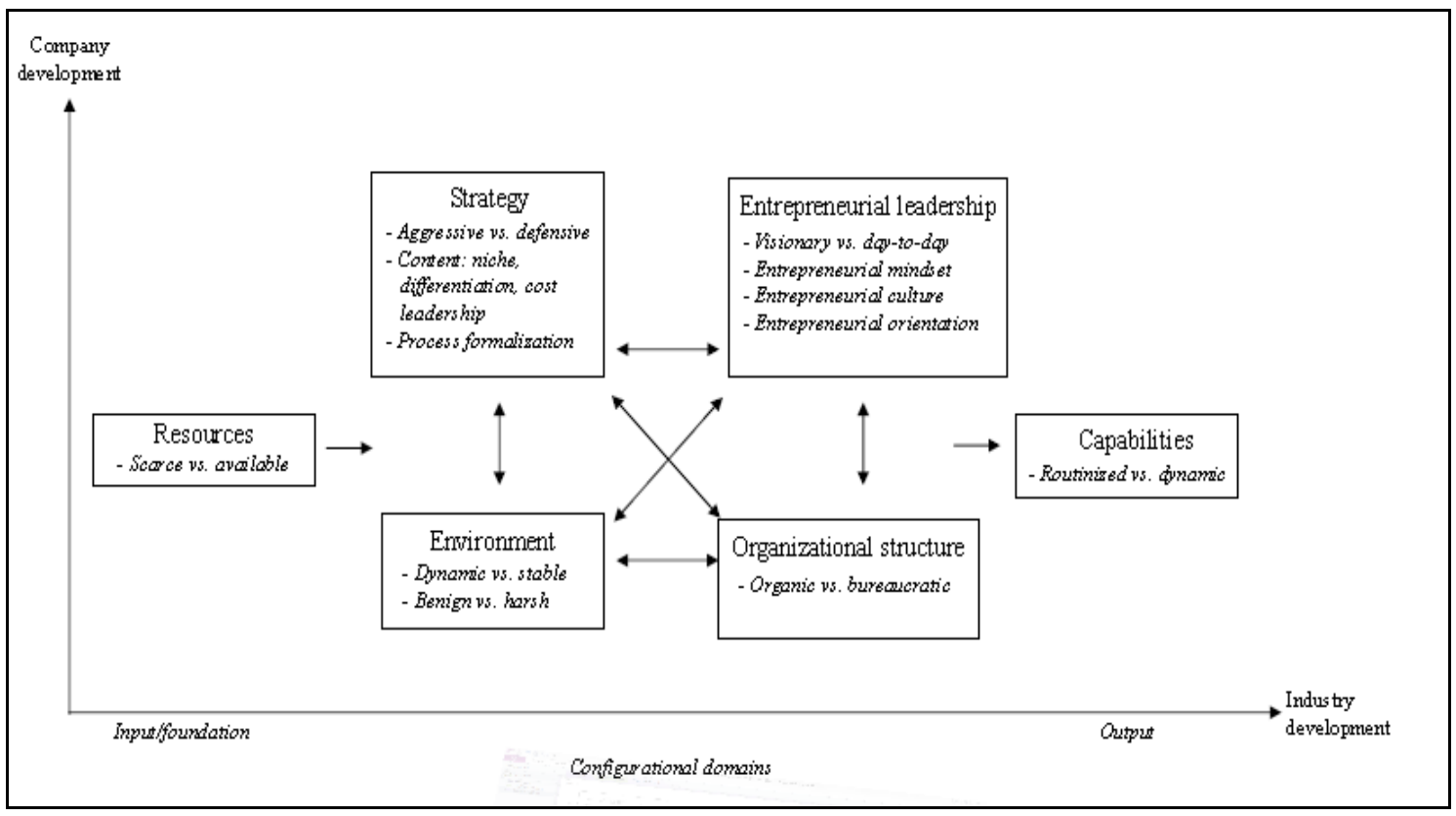

Gambar 3 Model yang dikembangkan Kraus et al., (2011)

\section{METODE}

Tulisan ini menggunakan metode kajian pustaka (Literature Review) untuk membahas topik yang dikaji. Kajian Pustaka dimaksudkan untuk memecahkan suatu masalah yang pada dasarnya bertumpu pada penelaahan kritis dan mendalam terhadap bahan-bahan pustaka yang relevan. Telaah pustaka dilakukan dengan cara mengumpulkan data atau informasi dari berbagai sumber pustaka yang diperlukan sebagai sumber ide untuk menggali pemikiran atau gagasan baru sebagai bahan dasar untuk melakukan deduksi dari pengetahuan yang sudah ada, sehingga kerangka teori baru dapat dikembangkan, atau sebagai dasar pemecahan masalah. Pendekatan literature review terdiri dari 5 tahap, yaitu: (1) Find models, (2) Problem formulation - which topic is under consideration and what are the constituent issues, (3) Literature search, (4) Evaluation of findings, dan (5) Analysis and interpretation of literature.

Sumber-sumber pustaka yang dikaji dalam tulisan ini berupa: buku, hasil penelitian, jurnal, dan artikel ilmiah lainnya. Langkah-langkah pembuatan literature review dijabarkan sebagai berikut: (a) menetapkan sumber-sumber untuk bahan literature review yang sesuai dengan topik kajian tulisan ini; (b) mengevaluasi isi yang dimuat di dalam sumber-sumber studi pustaka yang ditetapkan; bagian ini dapat memuat hal-hal yang berkaitan dengan anggapan-anggapan dasar atau fakta-fakta yang dipandang benar tanpa adanya verifikasi dan keterbatasan, yaitu aspek-aspek tertentu yang dijadikan kerangka berpikir; analisis ini diperlukan untuk menyusun alur berpikir dalam memecahkan masalah; (c) membuat summary terhadap isi sumber-sumber studi pustaka; (d) menggali pemikiran dan gagasan baru terhadap topik yang menjadi bahan kajian untuk menetapkan positioning konsep sebagai bahan penelitian berikutnya. 


\section{PEMBAHASAN}

\section{Konsep Strategy dan Strategic Management}

Manajemen strategis berkembang menjadi bidang riset sejak 1960-an, terutama melalui Chandler (1962), Ansoff (1965), dan buku teks Harvard dari Learned et al. (1965). Satu tujuan riset di bidang manajemen strategis adalah menganalisis bagaimana perusahaan dapat mencapai tujuan mereka dalam hubungannya dengan keunggulan kompetitif, laba dan profitabilitas (Rosen, 1995; Saloner et al., 2001 dalam Kraus et al., 2011). Dasar manajemen strategis adalah pemikiran bahwa strategi menciptakan keterpaduan antara kekuatan dan kelemahan internal perusahaan di satu sisi dan peluang serta ancaman eksternal di sisi lain (Andrew, 1987 dalam Kraus et al., 2011). Manajemen strategis berhadapan dengan bagaimana perusahaan mengembangkan sustainable competitive advantage (SCA) mengarah pada penciptaan nilai (Ireland et al, 2003; Ramachandran et al, 2006). Keunggulan kompetitif dihasilkan dari perbedaan nilai antara penawaran perusahaan dibandingkan dengan penawaran yang sesuai pesaing (Duncan et al., 1998). Kepemilikan sumber daya yang bernilai, jarang, tidak dapat ditiru, dan tidak dapat digantikan (Prahalad \& Hamel, 1990) dan juga posisi pasar yang menguntungkan (Porter, 1985) dianggap sebagai sumber utama SCA (Wernerfelt, 1984; Barney, 1991).

\section{Konsep Entrepreneurship}

Entrepreneurship merupakan bidang riset yang memiliki akar teoretis pada abad ke-18, ketika banker Irish Richard Cantillon (1755) menggunakan istilah ini untuk membedakan entrepreneur yang bekerja sendiri (self-employed entrepreneurs) dari pekerja yang dipekerjakan (employed workers) (Kraus et al, 2011). Dia yang pertama menghubungkan entrepreneurship dan pengambilan risiko berdasarkan kondisi ketidakpastian. Selanjutnya, elemen inovasi (Schumpeter, 1993 [1934]) dalam Kraus et al., (2011) dan perilaku proaktif melengkapi definisi ini (Miller, 1983). Saat ini, entrepreneurship umumnya dipertimbangkan menjadi stimulus untuk menciptakan nilai sebagai hasil dari tindakan perusahaan individual (Peng, 2001). Hal ini telah dianggap menjadi instrumen untuk mengatasi arena kompetitif baru dan kecepatan perubahan yang dahsyat (Brock \& Evans, 1989; Hitt \& Reed, 2000 dalam Kraus et al., 2011).

Entrepreneuship menjelaskan proses penciptaan nilai melalui identifikasi dan eksploitasi peluang seperti pengembangan produk baru atau mencari pasar baru atau keduanya (Shane \& Venkataraman, 2000; McCline et al., 2000). Entrepreneurship memfokuskan pada inovasi dengan identifikasi peluang pasar, yang pesaing belum diindentifikasi atau dimanfaatkan dan penciptaan serangkaian sumber daya yang unik untuk memanfaatkan peluang tersebut (Davidson et al., 2002). Peluang entrepreneurial muncul dari ketidakpastian. Serangkaian sumber daya yang tepat diperlukan untuk memanfaatkan peluang entrepreneurial (Hitt et al, 2002). Salah satu tantangan utama bagi entrepreneur adalah berhadapan dengan perubahan strategi yang diperlukan melalui pertumbuhan perusahaan mereka (Thompson, 1999).

\section{Strategic Entrepreneurship}

Titik temu riset entrepreneurship--opportunity seeking dan manajemen strategis--advantage seeking merupakan bidang baru riset yang disebut dengan SE (Strategic Entrepreneurship). Hal itu berhubungan dengan tindakan perusahaan melakukan dalam eksploitasi peluang (Ireland \& Webb, 2007). SE meliputi pengambilan tindakan entrepreneurial dengan orientasi manajemen strategis (Hitt et al., 2001a; Ireland et al., 2003). Kedua perspektif tersebut perlu untuk penciptaan nilai, tidak cukup sendiri saja (McGrath \& MacMillan, 2000). Jika entrepreneurship dipahami sebagai identifikasi dan penciptaan peluang baru dan jika strategis manajemen dipahami sebagai transformasi peluang ini ke 
dalam sustainable competitive advantage (Kuratko et al., 2005; Venkataraman dan Sarasvathy, 2001; Zahra dan Dess, 2001), pencarian peluang entrepreneurial dapat juga dianggap sebagai perilaku strategis dengan tujuan penciptaan nilai (Ireland et al., 2003; Ramachandaran et al., 2006). Banyak penulis telah menganjurkan arti penting variabel organisasional dan strategis untuk riset entrepreneurship, karena perilaku entrepreneurial merupakan arti penting utama bagi perusahaan jika mereka ingin berhasil dalam lingkungan kompetitif, tanpa menganggap ukuran dan usia perusahaan (Covin \& Slevin, 1989; Zahra, 1993). Dengan demikian, tidak ada kontradiksi mendasar antara kegiatan perencanaan strategis yang "rutinitas" dan pengambilan peluang "entrepreneurial". Kedua disiplin-strategic management dan entrepreneurship-sering saling melengkapi dan saling mendukung (Ireland et al., 2003). Sebagai contoh, riset telah menemukan secara konsisten bahwa perusahaan entrepreneurial lebih memanfaatkan instrumen manajemen strategis dibandingkan perusahaan konservatif (Shuman et al., 1985; Bracker et al., 1988; Woo et al., 1989).

\section{Domain Resources dan Capabilities}

Sumber daya dan kapabilitas saling berhubungan. Dalam penjelasan pertumbuhan organisasional, Penrose (1959) menekankan arti penting sumber daya manusia dan fisik dimediasi dengan kemampuan manajerial. Kemudian membangun kemampuan kognitif pelaku dan kemampuan mereka untuk mengatur interaksi antara sumber daya dalam memberikan layanan bagi organisasi, membangkitkan kapabilitas (Penrose, 1959). Dengan demikian, sesuai dengan resource-based view SE (Wernerfelt, 1984; Barney \& Wright, 2001) sumber daya dapat digabungkan dan dikembangkan dari waktu ke waktu untuk membangkitkan kapabilitas yang unik yang meningkatkan keunggulan kompetitif (Amit \& Schoemaker, 1993).

Studi empirik telah menunjukkan bahwa perbedaan ukuran dan usia perusahaan ditunjukkan dengan kombinasi sumber daya yang berbeda (Brush \& Chaganti, 1999; Mosakowski, 1993). Jenis sumber daya yang diperlukan bagi perusahaan tergantung pada lingkungan: perusahaan yang tumbuh cepat dalam lingkungan dinamis memerlukan sumber daya yang intangible (terutama sumber daya manusia entrepreneur), sementara perusahaan yang tumbuh moderat dalam lingkungan yang stabil biasanya membutuhkan sumber daya yang tangible (Lichtenstein \& Brush, 2001). Dalam tahap awal pertumbuhan perusahaan baru, identifikasi dan akuisisi sumberdaya biasanya lebih penting dibandingkan alokasinya (Katz \& Gartner, 1988). Hal ini sesuai dengan pembelajaran dalam uji coba model dalam lingkungan yang berubah cepat (Eisenhardt \& Martin, 2000). Bagaimanapun juga sebagai perusahaan baru yang tumbuh dan berubah, menjadi perlu memperoleh sumber daya baru atau mengubah sumber daya yang ada untuk mempertahankan kesesuaian perubahan dalam strategi produk/pasar dan dalam lingkungan (Chandler \& Hanks, 1994). Hal ini sesuai variasi path-dependent dalam manajemen strategis sesuai dengan pasar dinamis yang moderat (Teece et al., 1997).

\section{Domain Strategy}

Manajemen strategis berkaitan dengan keseluruhan arah dan visi perusahaan (bandingkan dengan operasi bisnis setiap hari) diimplementasikan oleh manajemen melalui kombinasi sumber daya dengan tujuan untuk membangun kapabilitas dalam lingkungan tertentu. Dalam konteks SE, kedua sisi manajemen strategis seperti content dan proses, telah meningkat dipelajari. Content mengacu pada strategi itu sendiri dan proses mengacu pada implemeentasi (Stacey, 1993). Dalam ruang lingkup content strategi ada strategi memasuki pasar untuk perusahaan baru atau SME meluncurkan produk baru. Posisi relatif perusahaan dalam pasar berpengaruh kuat terhadap kinerja perusahaan keseluruhan (Gruber, 2004). Porter (1985) menawarkan tiga strategi generik: (1) cost leadership, (2) differentiation, dan (3) focus on a niche market.

Perusahaan baru dan kecil jarang bisa mencapai keunggulan biaya karena tidak adanya skala ekonomis. Dengan demikian, peneliti merekomendasikan strategi niche seperti membidik segmen pasar yang sempit dan khusus yang dihindari oleh pesaing. Hal ini memungkinkan bagi perusahaan 
kecil dan baru untuk menetapkan posisi pasar dan mengembangkan sumberdaya yang perlu untuk bertahan jangka panjang (Lee et al., 2001; Bamford et al., 1997). Secara alternatif, perusahaan baru dan SME dapat mengikuti strategi diferensiasi dengan memberikan keunggulan khusus (seperti kepemimpinan kualitas) yang dinilai tinggi oleh konsumen. Untuk mencapai kinerja yang mungkin paling tinggi, setiap pilihan strategi perlu dihubungkan dengan sumber daya yang tepat (Borch et al., 1999). Dalam domain proses strategi, riset terutama telah terkonsentrasi pada hubungan antara perencanaan dan kinerja. Kajian literatur saat ini berkaitan dengan hubungan ini didasarkan pada 24 studi empirik dari 20 tahun terakhir menyatakan bahwa 79 persen dari studi yang dianalisis dapat mengidentifikasi hubungan positif antara perencanaan strategi dan kinerja perusahaan (Kraus et al., 2008). Melalui investigasi 248 perusahaan kecil dari Austria, studi yang sama juga dapat mengidentifikasi hubungan antara formalisasi perencanaan strategis dan pertumbuhan ketenagakerjaan.

\section{Domain Entrepreneur}

Entrepreneur adalah orang yang menemukan peluang dan memutuskan untuk mengejarnya (Kirzner, 1973; Casson, 1982; Schumpeter, 1993 [1934]) dengan mengembangkan kapabilitas organisasional berdasarkan sumber daya dalam konteks organisasi dan strategi khusus (Teece, 2007). Kesadaran entrepreneur merupakan hasil langsung proses penginderaan (sensing) dan dengan demikian dalam banyak kasus secara langsung berhubungan dengan kinerja perusahaan (McKenna, 1996). Dalam perusahaan baru dan kecil-menengah, entrepreneur (manajer-pemilik bisnis) biasanya pengambil keputusan utama dan ahli strategi, bertanggung jawab terhadap pengembangan dan juga implementasi keseluruhan visi, misi dan strategi perusahaan (Analoui \& Karami, 2003). Keputusan strategis oleh karenanya menggambarkan orientasi subjektif dan sikap entrepreneur. Sesuai tujuan pribadinya, sifat dan orientasi strategis memiliki dampak signifikan pada perilaku strategis perusahaan (McKenna, 1996). Meskipun telah sering dinyatakan bahwa tidak ada bisnis terlalu kecil memiliki strategi eksplisit (Sandberg et al., 2001), banyak entrepreneur memimpin bisnisnya pada basis day-today dan tidak merencanakan atau bertindak secara strategis. Bagaimanapun juga, untuk bertindak secara sukses, entrepreneur individu (juga intrapreneur) harus mengelola sumberdaya perusahaan mereka secara strategis dan dengan demikian terlibat dalam SE.

Untuk menggunakan proses model SE, Ireland et al. (2003), entrepreneur harus mengembangkan entrepreneurial mindset sebagai cara untuk berpikir yang memfokuskan pada identifikasi dan pemanfaatan peluang dalam menghadapi ketidakpastian. Mindset ini sejalan dengan orientasi pertumbuhan, entrepreneurial culture yang toleran terhadap kegagalan dimana individu mendorong fleksibilitas, kreativitas, inovasi terus-menerus dan pembaharuan (Ireland et al., 2003) dan entrepreneurial leadership yang mengacu pada kemampuan untuk mempengaruhi yang lain dan mengelola sumber daya secara strategis. Entrepreneurial leadership juga merupakan perilaku mencari peluang dan mencari keunggulan secara simultan (Ireland et al., 2003). Kebutuhan entrepreneurial mindset dihubungkan dengan EO (entrepreneurial orientation), memastikan bahwa mindset diubah ke dalam aktivitas. Entrepreneurial Orientation merupakan gejala individualistik dan kolektif (Covin \& Slevin, 2002). Beberapa riset telah menunjukkan bahwa Entrepreneurial Orientation memiliki dampak positif pada kinerja. Kebanyakan studi merumuskan Entrepreneurial Orientation sebagai budaya organisasional yang ditunjukkan dengan proactiveness, risk taking, dan innovativeness (Miller, 1983; Covin \& Slevin, 1989; Wiklund, 1999 dalam Ireland et al., 2003).

\section{Domain Environment}

Manajemen strategis sangat dipengaruhi oleh sumber daya yang berpengaruh pada lingkungan dinamis, stabil, dan ramah; struktur organisasi serta entrepreneurial leadership (Kraus et al., 2011). Semuanya mengarahkan pengembangan kapabilitas. Kemampuan untuk mengantisipasi dan kemudian menanggapi dengan tepat terhadap perubahan lingkungan melalui kapabilitas penginderaan yang trampil (Teece, 2007) merupakan salah satu input yang paling penting bagi Strategic Entrepreneurship 
(Ireland \& Webb, 2007). Dalam SE Strategic Entrepreneurship, identifikasi peluang membentuk dasar untuk memperoleh sumber daya baru dan pengembangan sumber daya yang ada untuk keseluruhan manajemen strategis bagi perusahaan baru atau perusahaan kecil-menengah untuk pemanfaatan peluang berikutnya. Oleh karenanya, identifikasi peluang adalah awal perilaku entrepreneurial (Gaglio \& Katz, 2001; Shane \& Venkataraman, 2000). Peluang juga merupakan dasar bagi perusahaan ketika mengembangkan sumberdaya dan kapabilitas, yang kemudian dapat mengarahkan keunggulan kompetiti dalam lingkungan yang berbeda (Alvesson \& Busenitz, 2001 dalam Kraus et al., 2011).

\section{Domain Organizational Structure}

Struktur organisasional dipertimbangkan sebagai basis implementasi strategi yang efektif, memungkinkan atau menghalangi pemanfaatan dan pencarian peluang. Struktur organisasional dirancang untuk membantu entrepreneur dalam mengalokasikan pekerjaan, sumber daya dan mekanisme administratif (yang meningkatkan kapabilitas) diperlukan untuk implementasi dan pengendalian strategi perusahaan (Analoui \& Karami, 2003 dalam Kraus et al., 2011). Perubahan dalam struktur perusahaan sering diperlukan saat perubahan strategis, masalah administratif dan inefisiensi ekonomi (Lynch, 1997 dalam Kraus et al., 2011). Dalam Strategic Entrepreneurship, struktur perusahaan seharusnya selalu menggambarkan budaya entrepreneurial (organisasional). Kemudian seharusnya membantu mengembangkan dan mendukung pencarian terus menerus bagi peluang entrepreneurial yang dapat dimanfaatkan dengan keunggulan kompetitif yang berkelanjutan (McGrath dan MacMillan, 2000 dalam Kraus et al., 2011). Struktur perusahaan tergantung pada dan membentuk sumber daya utama seperti finansial, manusia dan modal sosial (Sirmon dan Hitt, 2003 dalam Kraus et al., 2011).

\section{SIMPULAN}

Paper ini membahas tentang peran Strategic Entrepreneurship dalam membangun keunggulan kompetitif. Dalam bidang praktis, model Strategic Entrepreneurship dapat membantu perusahaan untuk memosisikan lebih baik dalam menghadapi perubahan lingkungan yang sedang berlangsung saat ini dan secara relatif mengembangkan sustainable competitive advantage. Dari beberapa hasil studi tentang pengembangan model Strategic Entrepreneurship, dapat disimpulkan bahwa Strategic Entrepreneruship memiliki peran yang sangat penting terutama dalam membangun keunggulan kompetitif dan kinerja organisasional. Dengan memahami secara lebih mendalam tentang ruang lingkup Strategic Entrepreneurship, diharapkan dapat meningkatkan pengetahuan tentang konsep

Strategic Entrepreneurship dan menemukan gagasan untuk penelitian lebih lanjut.

\section{DAFTAR PUSTAKA}

Barney, J. (1991). Firm resources and sustained competitive advantage. Journal of Management, 17(1), 99-120.

Covin, J. G. and Slevin, D. P. (1989). Strategic management in small firms in hostile and benignenvironments. Strategic Management Journal, 10(1), 75-87.

Eisenhardt, K. and Martin, J. (2000). Dynamic capabilities: what are they?, Strategi Management Journal, 21, 1105-1122.

Hitt, M. A., Ireland, R. D., Camp, S.M. and Sexton, D. L. (2001b). Guest editor's introduction to the special issue-strategic entrepreneurship: entrepreneurial strategies for wealth creation. Strategic Management Journal, 22(6/7), 479-491. 
Ireland, R.D., Hitt, M.A. and Simon, D.G. (2003). A model of strategic entrepreneurship: the construct and its dimensions. Journal of Management, 29(6), 963-989.

Ireland, R. D., Hitt, M. A., Camp, S. M. and Sexton, D. L. (2001). Integrating entrepreneurship andstrategic management actions to create enterprise wealth. Academy of Management Executive, 15(1), 49-64.

Kraus, S., Kauranen, I., Reschke, C. H. (2011). Identification of domains for a new conceptual model ofstrategic entrepreneurship usingthe configuration approach. Management Research Review, 34(1), 58-74.

Kyrgidou, P. P. \& Hughes, M. (2010). Strategic Entrepreneurship: Origins, Core Elements \& Research Directions. European Business Review, 22(1), 46-63.

Miller, D. (1983). The correlates of entrepreneurship in three types of firms. Management Science. 29(7), 770-91.

Peng, M. W. (2001). How entrepreneurs create wealth in transition economies. Academy of Management Executive, 15(1), 95-108.

Penrose, E. (1959). The Theory of the Growth of the Firm. New York: Wiley.

Porter, M. E. (1985). Competitive Advantage: Creating and Sustaining Superior Performance. New York: The Free Press.

Prahalad, C. K. and Hamel, G. (1990). The core competence of the corporation. Harvard Business Review, 68(3), 79-91.

Shulman, J. M., Cox, R. A. K., Oshawa, Stallkamp,T. T. (2011). Competitiveness Review: An International Business Journal, 21(1), 29-46.

Shane, S. and Venkataraman, S. (2000). The promise of entrepreneurship as a field of research. Academy of Management Review, 25(1), 217-2

Teece, D.J., Pisano, G. and Shuen, A. (1997). Dynamic capabilities and strategic management, Strategic Management Journal, 18, 509-533.

Venkataraman, S. and Sarasvathy, S. D. (2001). Strategy and entrepreneurship: outlines of an untold story. in Hitt, M. A., Freeman, E. and Harrison, J.S. (Eds). Handbook of Strategic Management, 650-668. Oxford: Blackwell.

Wernerfelt, B. (1984). A resource-based view of the firm. Strategic Management Journal, 5(2), 171180. 